\title{
THE EFFECT OF CORPORATE CITIZENSHIP ACTIVITIES (CCAS) ON FINANCIAL PERFORMANCE AND MARKET PERFORMANCE: THE OMANI EXPERIENCE
}

Mawih K. Shaker Al Ani , Syed Ahsan Jamil *

\section{Abstract}

The main objective of this study is to investigate and analyze the effects of corporate citizenship activities on the financial performance and market performance of Omani manufacturing companies in the Sultanate of Oman for the period 2009-2013. The Financial performance of companies is measured by two independent variables: return on assets (ROA) and return on equity (ROE). Market performance is measured by the fair market value of shares (FMV). CCAs are determined by the voluntary disclosures of corporate citizenship activities by the companies. The study concludes that there is a positive impact by CCAs on the financial and market performance of the Omani companies that leads to profit maximization.

Keywords: corporate citizenship activities, financial performance, fair market value of shares, return on assets and return on equity.

JEL classification: $G 32, L 25, L 1, M 14$

\section{INTRODUCTION}

Corporations around the globe are expected to meet the ever-growing expectation of contributing to the welfare of society as 'citizens". This expectation has grown as the world has become globalized and multinational companies are increasingly called upon to play the role of "global citizens'. Each corporation must share its economic gains with society and should focus not only on its shareholders but all stakeholders (Thomas and Preston 1995). A firm therefore must focus on not only increasing its economic gains but also being a good corporate citizen.

The term corporate citizenship is defined as the gamut of activities that develop the business - society relationship in such a manner that "business sees itself as part of public culture" (Birch, 2001). This concept represents an extension of other similar concepts such as social responsibility, corporate social performance and stakeholder theory, all of which depict the relationship between companies and their communities. By 1990 a debate began over the relative importance of the normative responsibilities which

\section{* Mawih K. Shaker Al Ani , Ph.D.}

Assistant Professor

Department of Accounting and Finance

College Of Commerce and Business Administration Dhofar University, Salalah, Sultanate of Oman mawih@du.edu.om

Syed Ahsan Jamil, Ph.D.

Associate Professor

Department of Accounting and Finance

College Of Commerce and Business Administration Dhofar University, Salalah, Sultanate of Oman

Syed_jamil@du.edu.om 
corporations are expected to render to society versus the 'desired activities' (Matten et al., 2003) which firms are expected to perform.

Many previous studies have examined the impact of corporate social responsibility (CSR) and corporate social performance on the financial performance and market performance of firms. Most of these studies have yielded mixed results. Some studies indicated a positive impact, others a negative impact and several studies failed to find any correlation. Few studies had examined the effects of corporate social responsibility or corporate citizenship on financial performance and market performance in the Middle East, particularly in the sultanate of Oman.

In this study an attempt has been made to investigate and analyze the effects of corporate citizenship activities (CCAs) on the financial and market performance of Omani Companies in three distinguished industrial sectors in Oman for the period 2009-2013. The study aims to get at the answer to the question: What are the effects of CCAs on the financial and market performance of Omani industrial firms?

CCAs are measured through the voluntary disclosure of social activities inside and outside Oman by Omani companies, financial performance is measured by the two common variables of return on assets (ROA) and return on equity (ROE), while market performance is measured by the fair market value of shares (FMV). Accordingly, the study develops two key hypotheses: CCAs have effects on the financial performance and market performance of companies.

The study is divided into five sections. In the first section, the study presents an introduction. Theoretical issues related to the concepts of corporate citizenship are presented in the second section. A literature review is discussed in the third section. The forth section presents the model, data and methodology used in this study. Section five provides the results of the analysis, while section six presents a summary and conclusions.

\section{THE CONCEPT OF CORPORATE CITIZENSHIP}

The concept of social responsibility has a long history in business. This history reflects the development of the concepts and practices of social responsibility, and dates back to the 1950s, when Corporate Social Responsibility (CSR) was introduced with the publication of Bowen's book The Social Responsibilities of Businessmen. CSR is a subset of corporate responsibilities that deals with a company's voluntary/ discretionary relationships with its community.

In the 1970s, a second concept, Corporate Social
Performance, was introduced in the literature. This concept focuses on the principles of social responsibility at the legitimacy, organizational and individual levels, and the processes of responsiveness (Valor 2005).

In the 1980s, a third concept, that of the Stakeholder, became dominant. Matten et al., (2003) explain that the stakeholder theory essentially argues that a company's relationships with stakeholders are at the core of understanding how it operates and adds value as a business.

In the late 1990s, practitioners introduced a new concept: corporate citizenship. This new concept is used to "connect business activity to broader social accountability and service for mutual benefit," enhancing the notion that a corporation is an entity with a status equivalent to that of a citizen (Valor 2005).

Wood (1991) defines the concept as the sum of socioeconomic activities that companies often undertake to fulfill their perceived duties as members of society.

Waddock and Graves (1997) define corporate citizenship as the strategies and practices that develop in to an operationalizing method. It has relationships with and impacts on stakeholders and the natural environment.

The World Economic Forum (2003) describes corporate citizenship as the group of policies and practices of a company in terms of their impacts on economic, environmental, and social parameters.

Corporate citizenship refers to businesses acting responsibly toward their stakeholders (Yasser 2011).

Matten et al. (2003) argue that a company enter the arena of citizenship at the point of government failure in the protection of citizenship.

According to the Center of International Private Enterprise, the concept looks beyond profits realized in the short term and takes into account the needs of various stakeholders, involves a high level of ethical standards, and creates a good environment for trade and investment. (Sullivan et al., 2004)

Pang (2010) pointed out that corporate citizenship is an advanced model of corporate social responsibility.

There are many other concepts related to social responsibility, such as strategic corporate social responsibility, strategic philanthropy, sustainability, corporate accountability, corporate moral agency and social entrepreneurship. The concept of social responsibility is regarded as a historical development of the social responsibility of corporations. This development reflects the relationship between corporations and community. Therefore, there are many differences between the abovementioned concepts and corporate 
citizenship. The most important differences are that CCA is more operational and comprehensive than other concepts. In this study, we focused on corporate citizenship as a modern concept in the area of social responsibility. We used corporate citizenship activities (CCAs) because there are great debates about the concept itself and it is still at a primary stage.

It should be noted that CCAs are not just activities carried out by companies from time to time for the benefit of society, but they are a variety of planned and comprehensive programs which reinforce the view that the corporation is a also a societal person who must carry out day to day activities to strengthen its relationship with society, such as pro bono activities, corporate volunteerism, charitable contributions, support for community education and health care initiatives, as well as environmental programs (Gardberg and Fombrun 2006).

In order to understand the philosophy and nature of the citizenship of a company, the Panasonic Company's CCA philosophy statement is a good example: "Panasonic is promoting corporate citizenship activities (social contribution activities) and working to solve social issues around the world, based on the philosophy of education and coexistence while focusing on two key areas: the environment and the next generation. This philosophy shows the role of Panasonic in the community: "The Company believes that business activities and corporate citizenship activities should be balanced like the wheels of a car, and they are working to promote both types of activities simultaneously in a manner that suits the times."

Therefore, Panasonic translated these ideas into activities on the ground where the Company exercises such activities in different countries of the world, such as in Russia, Tanzania, Romania, and Austria in addition to Japan (http://panasonic.net/citizenship).

In the sultanate of Oman there are many manufacturing companies who undertake corporate citizenship activities, such as the Raysut Cement Company, one of the biggest industrial companies in Oman, and which also has a section dedicated to corporate citizenship, showing the details of the company's CCA practices.

The company states in its sustainable development section: "...we are committed to the proactive integration of HSE (Health Safety Environment) objectives into our management system at all levels, actively reinforced by reward programs that recognize outstanding HSE performance demonstrated by our employees and contractors."

This section on sustainable development contains many subsections that serve as voluntary disclosure of CCAs, such as information of environment, health and safety, accountability, and management commitments (http://www.raysutcement.com.om/susdevelopment.htmlL.

Despite the ambiguity of the concept, some key features of the term are conclusive:

a) The concept of corporate citizenship overcomes the difficulties of operationalization and implementation as in other concepts such as corporate social responsibility.

b) The concept is a re-conceptualization of business-society relations.

c) The concept emphasizes the idea that corporations have the rights and duties of a person (Valor 2005).

d) The concept combines ethical, social, environmental and economic issues.

e) The concept meets the needs of stakeholders rather than stockholders.

f) The concept includes strategies, policies and practices to connect business and community.

g) The citizenship concept is not a distribution of profit to stakeholders, but investment in the society.

h) The concept embodies a communitarian approach.

\section{LITERATURE REVIEW}

Academic studies on the concept of Corporate Citizenship and its impact on financial and market performance are still at an early stage, and few studies have been carried out in this area.

Meijer and Schuyt (2005) analyzed the behavior of Dutch consumers towards corporate social performance. They found that the corporate social performance of producers does not encourage consumers to buy a product.

Gardberg and Fombrun (2006) examined the relationship between citizenship programs implemented by multinational companies and intangible assets. They supposed that these programs "can create intangible assets that help companies overcome nationalistic barriers, facilitate globalization, and outcompete local rivals". Their study concluded that corporate citizenship provides an appropriate application of strategic balance theory between legitimating and differentiation.

Fiori et al., (2007) examined the impact of voluntary disclosure about CSR on the stock prices of Italian listed companies over the period of 2002-2007. The results indicated that disclosure about some CSR activities leads to higher stock prices because of the prevalence of a good perception on the market. 
Makni et al., (2009) examined the relationship between corporate social and financial performance in Canadian firms. They found no relationship between their corporate social responsibility and financial performance, though they did identify a negative relationship between environmental factors and financial performance.

Blazovich and Smith (2009) explored the relationship of ethical corporate citizenship to financial performance (greater profitability and efficiency, and lower cost of capital) and market-value premiums. They used firms listed by Business Ethics as "The 100 Best Corporate Citizens" as a sample of ethical firms. The results of the study show a significant relationship between ethical corporate behavior and financial performance, but no relationship between being recognized as ethical at least once and the market value of equity. They concluded that ethical corporate citizenship does indeed benefit a firm.

El Ghoula et al. (2011) tested the relationship between corporate social responsibility and cost of capital for a large sample of U.S. firms. They found that CSR companies have cheaper equity financing, and that this reduces the cost of capital.

Hamid et al., (2011) tested the relationship between corporate social responsibility and financial leverage measured by debt equity ratio and found that financial leverage (the debt to equity ratio) has a significant correlation of 0.10 at a 0.05 level of significance.

Setiawan and Janet (2011) argued that there is a relationship between corporate social responsibility, financial performance, and market performance. They used a sample of consumer goods companies in the Indonesian Stock Exchange during 2007-2010. They concluded that corporate social responsibility increased financial performance (ROA), but had no significant effect on market performance.

Uadiale and Fagbemi (2012) investigate the impact of CSR activities on Return on Equity (ROE) and Return on Assets (ROA) in Nigerian companies. The results indicate that CSR has a positive and significant relationship with financial performance measures.

Babalola (2012) examined the relationship between corporate social responsibility and firms' profitability in Nigeria. The result showed that the explanatory variable account for changes or variations in selected firms' performance is caused by changes in corporate social responsibility (CSR) in Nigeria.

Mulyadi and Anwar (2012) examined the relationship between corporate social responsibility and profitability and firm value. They used several variables to measure firm value and profitability, such as leverage. They concluded that there is no significant relationship between leverage and firm value.
Servaes and Tamayo (2013) argued that corporate social responsibility (CSR) and firm value are positively related to firms having high customer awareness using the proxy of advertising expenditures. For firms with poor customer awareness, the relation is either negative or insignificant. In addition, they found that the effect of awareness on the firm value-CSR relationship is reversed for firms with a poor prior reputation as corporate citizens.

Pauly et al., (2013) examined the relationships between the size of the company and corporate social responsibility in Swiss MNCs and SMEs. They suggested that smaller firms are not necessarily less advanced in organizing CSR than large firms. The main conclusion of the study is that unlike small firms the "large multinational corporations possess several traits that enhance communication and reporting about CSR."

Cheng et al., (2014) investigated whether superior performance on corporate social responsibility (CSR) strategies leads to better access to finance. They found a positive relationship between corporate social responsibility and a flexible financing structure, and that CSR performance is important in reducing capital constraints.

Gregory et al., (2014) examined the impact of corporate social responsibility on the risk and effects of risk on cost of capital, cash flows and the value of returns, finding "that the cost of capital thereby was reduced; the present value of the cash flows would rise, leading to an increase in the value of returns."

Most of these studies discussed the relationship between corporate citizenship, corporate social responsibility and variables such as financial performance indicators (profit, cost of capital and market value), the loyalty of customers, productivity, and so on. Table 1 depicts a summary of results CSR /CCAs studies.

According to these studies, there is an overlap between the two concepts of corporate citizenship and corporate social responsibility such that they can be used interchangeably. In addition, these studies do not agree in their results. Among other reasons, this is because they used different approaches or methodologies.

It may be noted that the literature review discusses the association between CCAs and financial performance and market performance around the world, but there are very few studies that discuss its impact in the Arab world generally, nor specifically in Oman. Unfortunately, the amount of literature concerning corporate citizenship or corporate social responsibility in Oman and the Gulf Cooperation Council Countries (GCC) is very limited. This is because CSR and CCA in the sultanate of Oman and other Middle Eastern 
Table 1. Summary of the results of CSR and CCAs studies

\begin{tabular}{|c|c|c|c|c|}
\hline Author (s) & Year & Dependent Variables & $\begin{array}{l}\text { Independent } \\
\text { Variable (CSR/ CC) }\end{array}$ & Results \\
\hline Meijer and Schuyt & 2005 & Loyalty of Customers & CSR & No relationship \\
\hline $\begin{array}{l}\text { Gardberg and } \\
\text { Fombrun }\end{array}$ & 2006 & Intangible Assets & $\mathrm{CC}$ & Positive relationship \\
\hline Fiori et al. & 2007 & Stock Prices & CSR & Positive \\
\hline Makni et al. & 2009 & Financial Performance & CSR & Negative relationship \\
\hline Blazovich and Smith & 2009 & $\begin{array}{l}\text { Profitability, Efficiency, } \\
\text { Productivity and Lower Cost } \\
\text { of Capital and Market-Value } \\
\text { Premium }\end{array}$ & $\mathrm{CC}$ & $\begin{array}{l}\text { Positive relationship with } \\
\text { Financial Performance- No } \\
\text { relationship with market } \\
\text { performance }\end{array}$ \\
\hline El Ghoula et al. & 2011 & Cost of Capital & CSR & Positive \\
\hline Hamid et al. & 2011 & $\begin{array}{l}\text { Financial Leverage (debt to } \\
\text { equity Ratio }\end{array}$ & CSR & Positive \\
\hline Setiawan and Janet & 2011 & ROA/ Market Value of Share & CSR & $\begin{array}{l}\text { Positive with ROA- No rela- } \\
\text { tionship with Market Value }\end{array}$ \\
\hline Uadiale and Fagbemi & 2012 & ROE/ROA & CSR & Positive \\
\hline Babalola & 2012 & Profitability & CSR & Positive \\
\hline Mulyadi and Anwar & 2012 & Profitability and Firm Value & CSR & No relationship \\
\hline Pauly et al. & 2013 & Size of the Company & CSR & Positive \\
\hline Servaes and Tamayo & 2013 & Firm Value & $\mathrm{CSR} / \mathrm{CC}$ & Positive \\
\hline Cheng et al. & 2014 & Financing Structure & CSR & Positive \\
\hline Gregory et al. & 2014 & Risk/ Cost of Capital & CSR & Positive \\
\hline
\end{tabular}

countries remain at an early stage of development, and hence very few studies have been carried out in this region. In addition, these countries are still at the stage of trying to define CSR in their own context, map their stakeholders, and define their priority issues (Background Paper 2007).

\section{MODEL, METHODOLOGY AND DATA HYPOTHESES AND DATA}

\subsubsection{CCAs and financial performance}

Despite the fact that previous studies differ in their results, most of them agreed that CSR or CCA have some effect on the financial performance and market performance of firms. In this frame, the activities of corporate citizenship may have positive or negative relations based on each study. In terms of positive impact, CCAs may lead to competitive advantages and improve the financial performance and market performance of companies. This means that an increase in CCAs will increase both types of performance insofar as CCAs are correctly priced by the market. The study by Setiawan and Janet(2011) establishes that CSR activities may increase the demand for products and/or services by reducing consumer price sensitivity. CSR attracts socially conscious consumers to increase their purchases of a company's products and can actually lure them away from competitors. This results in protecting and enhancing the reputation of the company. The final impact of all of these actions is to actually improve the company's performance and profitability.

On the other hand, if CCAs are incorrectly priced by the market and fail to meet the needs of this market, a negative relationship between CCAs and financial performance may appear. Therefore the hypothesis is: CCAs will effect (positively or negatively) the financial performance of companies.

\subsubsection{CCAs and market performance}

The prices of shares are an indicator for the market performance of companies, and should reflect the invested value of CCAs. The market increasingly views CCAs as a tool to reduce risk management and improve corporate governance. Logically and practically, 
higher financial performance will lead to a better market response and higher stock price.

But a negative relationship may appear if the market and investors discovered that the objective of CCAs is to maximize the profit not providing a service to the society. This relationship means that the CCAs are not efficiently priced by market. Babalola $(2012$, p.44) indicated that "if investors believed that companies implementing the corporate social responsibility principles are resource wasteful, they would determine a negative return premium on these companies' stocks". If the market and investor find out that the purpose of CCAs was seeking profit, the prices of shares do not efficiently reflect the CCAs where any increase in CCAs will not lead to an increase in the prices of shares or market performance. Therefore, the hypothesis is that CCAs will affect (positively or negatively) the market performance of companies.

\subsection{Sources of data and methodology}

This study depends mainly on secondary data obtained from the financial statements of (38) companies listed on Muscat Securities Market (MSM). The methodology of the study is content analysis of annual reports of a sample of 38 companies out of 48 (79\%): 18 out of the $18(100 \%)$ companies in the food sector, 10 out of the $10(100 \%)$ in the construction sector and 10 out of the $10(100 \%)$ companies in the chemical sector for the period 2009-2013. The study excluded 10 companies ( 4 from the mechanical sector, 2 from the textile sector and 4 from the mining sector) due to the insufficient availability of required data for these companies.

From the annual reports for the selected companies, the value of the three determinants ROA, ROE and FMV were taken for testing by using the statistical package for the social sciences (SPSS) software. The CCAs are measured by the voluntary disclosure of such activities. MSM itself started to make the annual reports available for its listed companies in 2007, thus making it difficult to get the required data for an extended period. In order to establish the impact of CCAs on the determinants, regression analysis, utilizing the ordinary least squares method, is used to test the hypothesis.

\subsection{Sample selection}

In order to test the relationships between the CCAs and financial and market performance of these companies, we have selected a total of 38 companies from three important sectors of the country which are also listed on (MSM) the only stock exchange of Oman. The sectors selected were: food, construction and chemicals. There are many reasons for selecting these three sectors. First, 18 companies out of $38(47 \%)$ have corporate citizenship or corporate social responsibility activities, which is a higher rate than any other sectors in Oman. Second, the industrial sector in Oman is more interesting regarding CCAs because the Omani people still have a negative view toward industrial companies. Finally, of the total 48 of companies that are listed in the industrial sector, there are 38 companies that can be grouped into three sub-sectors as in the MSM and as shown in Table2 below.

Table 2. Population and Samples

\begin{tabular}{|l|c|c|r|r|r|}
\hline Sector & $\begin{array}{c}\text { Popul- } \\
\text { ation }\end{array}$ & $\begin{array}{c}\text { No. of } \\
\text { sample }\end{array}$ & $\%$ & CCAs & $\begin{array}{c}\text { No } \\
\text { CCAs }\end{array}$ \\
\hline Food & 18 & 18 & $100 \%$ & 8 & 10 \\
\hline Construction & 10 & 10 & $100 \%$ & 6 & 4 \\
\hline Chemicals & 10 & 10 & $100 \%$ & 4 & 6 \\
\hline Mining & 4 & - & - & & \\
\hline Textile & 2 & - & - & & \\
\hline Mechanical & 4 & - & - & & \\
\hline Total & 48 & 38 & $79.1 \%$ & 18 & 20 \\
\hline
\end{tabular}

\subsection{Models Specification}

This study examines impact of Corporate Citizenship Activities on financial performance and market performance in Oman. The study employs an econometric method in formulating a regression model to be analyzed through ordinary least squares regression (OLS). The methodology employed in the study was to examine the annual report of the selected companies

$$
\begin{array}{ll}
\text { Equation 1 } & \text { ROEit }=\alpha 0+\beta C C \text { Asit }+ \text { it } \\
\text { Equation 2 } & \text { ROAit }=\alpha 0+\beta C \text { Asit }+ \text { it } \\
\text { Equation 3 } & \text { FMVit }=\alpha 0+\beta C C \text { Asit }+ \text { cit }
\end{array}
$$

using the following three regressions:

Notes:

ROE: Return on Equity

$\mathrm{ROA}=$ Return on Assets

$\mathrm{FMV}=$ Market Fair Value of share 


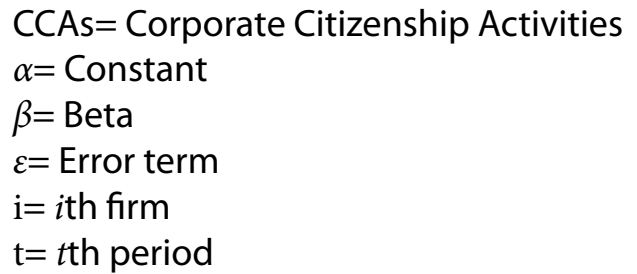

For the purpose of this study the OLS method is used and the parameter estimate obtained by the OLS is adopted because it is a fairly simple computational procedure and the data requirements are not too concessive.

\section{RESEARCH FINDINGS}

\subsection{CCAs and Firm Performance in three sectors together}

The study examines the relationship between CCAs and financial performance and market performance.

Table 3 shows the correlations and the regression results of a sample of 38 industrial companies.

As in the table 3, it seems that there is a statistically positive correlation between CCAs and ROE at $5 \%$. On the other hand, there are no statistically significant correlations between CCAs and FMV and ROA at the $5 \%$ level. Regression analysis indicates that CCAs have impact only on ROE. The R-squared is $18.7 \%$ and the Sig-Value is 0.007 , which is less than the P-value0.05. It can be deduced from the results that CCAs have a significant effect on financial performance in terms of ROE but have no significant effect on ROA and FMV. This means that Omani Manufacturing Companies with good CCAs will achieve a good ROE. In addition, this means that these Companies try to maximize profits when doing corporate citizenship activities. This indicates that there is a weak awareness for the real concept of corporate citizenship on the part of companies and investors.

\subsection{CCAs and Firm Performance in the Food, Construction and Chemicals Sectors}

Table 4 depicts the results of associations and regressions for all three sectors selected individually.

As shown in Table 4, in the Food sector there are no associations between CCAs and FMV, ROA and ROE. None of the correlations are significant at 5\%. Also, the regression models are not significant at $5 \%$ since the Sig. values for all $(0.701,0.136,0.711)$ are greater than $5 \%$ and the R-squares do not support the regression models any of the three dependent variables.

In the construction sector, the results show that there is a significant association between CCAs and ROE. On the other hand, there are no associations between CCAs and ROA and FMV at 5\%. Regression analysis showed that the CCAs have an impact on ROE only at $5 \%$. The R- Square results support the model, as the R-Square interprets $62.9 \%$ of the total variance in ROE. The associations and regressions between CCAs and FMV and between CCAs and ROA are not significant at $5 \%$ and the R-Squares do not support these associations and regressions.

In the Chemicals sector, the results show that there is a significant association between CCAs and ROE. On the other hand, there are no associations between CCAs and ROA and FMV at 5\%. Regression analysis shows that the CCAs have an impact on ROE only at $5 \%$. The R- Square results support the model, as the R-Square interprets $75.5 \%$ of the total variance in ROE. The associations and regressions between CCAs and FMV and between CCAs and ROA are not significant at the $5 \%$ level and the R-Squares do not support these associations and regressions.

Table 3. Summary of Correlations and Regression for Omani Industrial Sector (38 Companies)

\begin{tabular}{|c|c|c|c|c|c|c|c|c|c|}
\hline \multirow[t]{2}{*}{ Model } & \multirow{2}{*}{$\begin{array}{l}\text { Independent } \\
\text { Variable }\end{array}$} & \multirow[t]{2}{*}{ Correlation } & \multirow{2}{*}{$\begin{array}{c}\text { Dependent } \\
\text { Variables }\end{array}$} & \multirow[t]{2}{*}{ R-Squared } & \multirow[t]{2}{*}{ F-Value } & \multirow[t]{2}{*}{ Sig. } & \multicolumn{3}{|c|}{ Coefficients } \\
\hline & & & & & & & Variables & T-Value & Sig. \\
\hline \multirow{6}{*}{1} & \multirow[t]{6}{*}{ CCAs } & \multirow[t]{2}{*}{0.069} & \multirow[t]{2}{*}{ FMV } & \multirow[t]{2}{*}{0.005} & \multirow[t]{2}{*}{0.171} & \multirow[t]{2}{*}{0.682} & Constant & 0.754 & 0.456 \\
\hline & & & & & & & CCAs & 0.413 & 0.682 \\
\hline & & \multirow[t]{2}{*}{0.145} & \multirow[t]{2}{*}{ ROA } & \multirow[t]{2}{*}{0.021} & \multirow[t]{2}{*}{0.776} & \multirow[t]{2}{*}{0.384} & Constant & 2.028 & 0.050 \\
\hline & & & & & & & CCAs & 0.881 & 0.384 \\
\hline & & \multirow[t]{2}{*}{$0.433^{* *}$} & \multirow[t]{2}{*}{ ROE } & \multirow[t]{2}{*}{0.187} & \multirow[t]{2}{*}{8.305} & \multirow[t]{2}{*}{0.007} & Constant & 1.767 & 0.086 \\
\hline & & & & & & & CCAs & 2.882 & 0.007 \\
\hline
\end{tabular}

** Correlation is significant at the 0.05 level (2-tailed). 
Table 4. Summary of the results of associations and regressions for the Food, Construction and Chemical sectors

\begin{tabular}{|c|c|c|c|c|c|c|c|c|c|}
\hline \multirow[t]{2}{*}{ Model } & \multirow{2}{*}{$\begin{array}{l}\text { Independent } \\
\text { variable }\end{array}$} & \multirow[t]{2}{*}{ Correlation } & \multirow{2}{*}{$\begin{array}{l}\text { Dependent } \\
\text { Variables }\end{array}$} & \multirow[t]{2}{*}{ R-Squared } & \multirow[t]{2}{*}{ F-Value } & \multirow[t]{2}{*}{ Sig. } & \multicolumn{3}{|c|}{ Coefficients } \\
\hline & & & & & & & Variables & T-Value & Sig. \\
\hline \multirow{6}{*}{ Food sector } & \multirow{6}{*}{ CCAs } & \multirow[t]{2}{*}{0.097} & \multirow[t]{2}{*}{ FMV } & \multirow[t]{2}{*}{0.009} & \multirow[t]{2}{*}{0.153} & \multirow[t]{2}{*}{0.701} & Constant & -1.404 & 0.179 \\
\hline & & & & & & & CCAs & 0.391 & 0.701 \\
\hline & & \multirow[t]{2}{*}{0.366} & \multirow[t]{2}{*}{$\mathrm{ROA}$} & \multirow[t]{2}{*}{0.134} & \multirow[t]{2}{*}{2.468} & \multirow[t]{2}{*}{0.136} & Constant & 0.601 & 0.556 \\
\hline & & & & & & & CCAs & 1.571 & 0.136 \\
\hline & & \multirow[t]{2}{*}{0.094} & \multirow[t]{2}{*}{ ROE } & \multirow[t]{2}{*}{0.009} & \multirow[t]{2}{*}{0.143} & \multirow[t]{2}{*}{0.711} & Constant & -0.897 & 0.383 \\
\hline & & & & & & & CCAs & 0.387 & 0.711 \\
\hline \multirow{8}{*}{$\begin{array}{l}\text { Construction } \\
\text { Sector }\end{array}$} & \multirow{8}{*}{ CCAs } & & & & & & & efficients & \\
\hline & & & & & & & Variables & T-Value & Sig. \\
\hline & & \multirow{2}{*}{0.192} & \multirow[t]{2}{*}{ FMV } & \multirow{2}{*}{0.037} & \multirow{2}{*}{0.307} & \multirow{2}{*}{0.595} & Constant & 1.964 & 0.850 \\
\hline & & & & & & & CCAs & 0.554 & 0.595 \\
\hline & & בח20 ח- & ROA & - 0070 & 034 & 0.574 & Constant & 1.321 & 0.223 \\
\hline & & -0.203 & & $-0.0 / 9$ & 0.344 & & CCAs & -.587 & 0.574 \\
\hline & & ด 792** & $\mathrm{R} \cap \mathrm{F}$ & (2) & 12580 & (0006 & Constant & 1.938 & 0.089 \\
\hline & & 0.193 & nUᄃ & 0.029 & 13.509 & 0.000 & CCAs & 3.686 & 0.006 \\
\hline & & & & & & & & efficients & \\
\hline & & & & & & & Variables & T-Value & Sig. \\
\hline Chemical & CCAs & -0.528 & FMV & 0.278 & 3.087 & 0.117 & Constant & 5.635 & 0.000 \\
\hline sector & & & & & & & CCAs & -1.757 & 0.117 \\
\hline & & 0.132 & ROA & 0.017 & 0.142 & 0.716 & Constant & 1.987 & 0.082 \\
\hline & & & & & & & CCAs & 0.377 & 0.716 \\
\hline & & $0.869^{* *}$ & ROE & 0.755 & 24.671 & 0.001 & Constant & 5.236 & 0.001 \\
\hline & & & & & & & CCAs & 4.967 & 0.001 \\
\hline
\end{tabular}

** Correlation is significant at the 0.05 level (2-tailed).

\subsection{F-test results}

We use the F- test to examine the differences between the three sectors related to CCAs. Table 5 shows the results of this test. As shown in the table 5, the results indicate that there are no differences between the three sectors concerning the CCAs, where the Sig. 0.651 is greater than 0.05 .

\section{SUMMARY AND CONCLUSIONS}

This study aims at identifying the effects of CCAs on the financial and market performance of Omani manufacturing for the period of 2009-2013. Financial performance is measured by two independent variables: return on assets (ROA) and return on equity (ROE), while market performance is measured by fair

Table 5. ANOVA analysis for Differences between three sectors

\begin{tabular}{|l|c|c|c|c|c|}
\hline CCAs & Sum of Squares & df & Mean Square & F & Sig. \\
\hline Between Groups & 0.229 & 2 & 0.115 & 0.434 & 0.651 \\
\hline Within Groups & 9.244 & 35 & 0.264 & & \\
\hline Total & 9.474 & 37 & & & \\
\hline
\end{tabular}


market value of shares (FMV). The CCAs are measured by voluntary disclosures of corporate citizenship activities undertaken by the companies. The study analyzed the annual reports for 38 (out of 48) manufacturing companies in three distinguished sectors; Food (18 companies), Construction (10 companies) and Chemicals (10 companies).

The study tested two hypotheses about the effect of CCAs on financial performance and market performance. The study built its hypotheses based on the results of literature reviews. The results of those studies were mixed, with some indicating positive effects and others negative effects. Few studies examined the effects of corporate social responsibility or corporate citizenship on financial performance and market performance in Oman. This is true not only of Oman but in Arab countries as a whole, where studies in this area are very limited.

For the 38 companies examined in this study, the results of statistical analysis indicate that there are positive correlations and regression at $5 \%$ levels of significance between CCAs and ROE. The R-square is $18.7 \%$ of total variance, which means that the CCAs interpret only $18.7 \%$ of any variance in $\mathrm{ROE}$, or to a low degree. Also, the results indicate that there are no correlation and regression results at $5 \%$ levels of significance between CCAs and ROA and FMV.

For the food sector, the results indicate that there are no correlation and regression results at $5 \%$ levels of significance between CCAs and ROA and FMV.

For the Construction and Chemicals sectors, the results of statistical analysis indicate that there are positive correlations and regression results at $5 \%$ levels of significance between CCAs and ROE. The R-square results are $62.9 \%$ and $75.5 \%$ of total variance, respectively, supporting the results of the model. In addition, the results indicate that there are no correlation and regression results at $5 \%$ levels of significant between CCAs and ROA and FMV.

The overall results of the study are that manufacturing companies in Oman support profit maximization through corporate citizenship activities. This may be because the market and market participants increasingly view CCAs as a profit-seeking investment and not as a social investment.

The results of this study support the results of previous studies, such as Fiori et al., (2007) and Setiawan and Janet (2011) which suggest that there are no effects of CCAs (CSR) on market performance. Finally, the results of this study agree with the majority of previous studies, such as Blazovich and Smith (2009); Uadiale and Fagbemi (2012) and Babalola (2012), in suggesting that there is a positive relationship between CCAs (CSR) and financial performance.
As with other research, the present study has some limitations. Due to limited available information on the companies listed on the MSM, annual reports for only five years (2009-2013) were analyzed because only these reports were present on the websites of these companies and the MSM. At the same time, the disclosure of CCAs by companies is very limited. Therefore, further research is required. For example, testing financial and market performance in other sectors in Oman could be done, as this issue has not been researched in depth. Another research area of interest would be exploring the possible reasons explaining the differences between sectors concerning the relationship between corporate citizenship activities and financial and market performance.

\section{REFERENCES}

Babalola, Y. A. 2012. The Impact of corporate social responsibility on firms' profitability in Nigeria, European Journal of Economics, Finance and Administrative Sciences, 45. Retrieved from: http://www.eurojournals.com/EJEFAS. htm (accessed February 2013).

Background Paper. 2007. Corporate Social Responsibility and Corporate Citizenship in the Arab World. Paper presentedin the CSR Conference in Cairo, Egypt, on November 21-22

Baker, K. H., and Powell, G. E. 2005. Understanding Financial Management a Practical Guide. United Kingdom, CA: Black well Publishing.

Birch, D. 2001. Corporate citizenship: Rethinking business beyond corporate social responsibility. In Perspectives on Corporate Citizenship, edited by J. Andriof and $M$. McIntosh, 53-65. Greenleaf, Sheffield.

Blazovich, J. L. and Smith, L. M. 2009. Ethical corporate citizenship: Does it pay? Paper presented at the symposium on ethics research in Accounting, American Accounting Association CA: USA. Retrieved fromwww.cebcglobal. org/uploaded_files/Ethical_Corporate_Citizenship.pdf (accessed October 2012).

Cheng, B., loannis I.,and George S. 2014. Corporate social responsibility and access to finance, Strategic Management Journal, 35, 1-23.

Corporate citizenship. (n.d). Retrieved June 09, 2014, from Panasonic Company website, http://panasonic.net/ citizenship.

El Ghoula, S., Guedhamib, O., Kwokb, C. C. Y., and Mishrac, D. R. 2011. Does corporate social responsibility affects the cost of capital? Journal of Banking and Finance, 35(9): 2388-2406.

Fiori, G., di Donato, F. and Izzo, M. F. 2007. Corporate Social responsibility and Firms Performance- An Analysis on 
Italian Companies. Retrieved from http://ssrn.com/abstract $=1032851$ (accessed December 2013).

Gardberg,N.A., and Fombrun,C.J.2006.Corporatecitizenship: Creating intangibleassets across institutional environments. Academy of Management Review 31(20): 329-346.

Gregory, A., Tharyan, R., and Whittaker, J. (2014). Corporate social responsibility and company value. Journal of Business Ethics 124 (4):633-657.

Hamid, K., Rana. S. I. A., Asghar, M.,and Ahmad, S. 2011. Corporate social performance, financial performance and market value behavior: An information asymmetry perspective. African Journal of Business Management 5(15): 6342-6349, 4 August.

Makni, R., Claude, F., and Francois, B. 2009. Causality between corporate social performance and financial performance: Evidence from Canadian firms. Journal of Business Ethics 89(3): 409-422.

Matten, D. Crane, A. and Chapple, W. 2003. Behind the mask: Revealing the true face of corporate citizenship, Journal of Business Ethics 45(1):109-120.

Meijer, M. M., and Schuyt, T. 2005. Corporate social performance as a bottom line for consumer, Business and Society 44, 442-461.

Mulyadi, M. S.,and Anwar, Y. (2012). Impact of corporate social responsibility toward firm value and profitability. The Business Review 19 (2): 316-324.

Pang, K. C. 2010. Moral development of youth in Hong Kong: Towards a model of immersion through corporate citizenship - An Advanced Model of Corporate Social Responsibility.Journal of Youth Studies 13 (2) (Serial No. 26): 103-112.

Pauly, D. B., Wickert, C. Spence, L. and Scherer, A., G. 2013. Organizing corporate social responsibility in small and large firms: Size matters. Journal of Business Ethics 115(4): 693-705.

Servaes, H., and Tamayo, A. 2013. The Impact of corporate social responsibility on firm value: The Role of customer awareness, Management Science 59 (5):1045-1061.
Setiawan, E., andJanet, T. G. 2011. Corporate social responsibility, financial performance, and market performance: Evidence from Indonesian consumer goods industry. Paper presented at the $6^{\text {th }}$ Asian Business Research Conference, 9-10 April, University of Surabaya, Indonesian. Retrieved from www.wbiconpro.com/107Evelyn.pdf (accessed February 2013).

Suillvan, J. D., Shkolinkov, A., and Lichman, J. 2004. Corporate citizenship and its applications in business filed. Retrieved from Centre of International Private Enterprise.website: http://www.cipearabia.org/files/pdf/ Corporate_Citizenship/Business_Case_for_Corporate_ Citizenship.pdf (accessed October 2012).

Sustainable development. (n.d.). Retrieved September 22, 2014, from Raysutcement Company website, http:// www.raysutcement.com.om/susdevelopment.html.

Thomas D. and Preston L. E. 1995. The Stakeholder theory of the corporation: Concepts, evidence and implications. The Academy of Management Review 20(1): 65-91.

Uadiale, O. M., and Fagbemi, T. O. 2012. Corporate social responsibility and financial performance in developing economies: The Nigerian experience. Journal of Economics and Sustainable Development 3(4): 44-54.

Valor, C. 2005. Corporate social responsibility and corporate citizenship: Towards corporate accountability. Business and Society Review 110(2): 191-212.

Waddock, S. A., and Graves, S. B. 1997. The Corporate social performance- financial performance link. Strategic Management Journal 18(4): 303-319.

Wood, D. J. 1991. Corporate social performance revisited. Academy of Management Review 16: 691-718.

World Economic Forum. 2003. Global competitiveness reports (2003-4). Retrieved from World Economic Forum website: http:// www.weforum.org/issues/global-competitivenes (accessed May 2014).

Yasser, R. Q. 2011. Corporate citizenship: A new peak. Retrieved from: http://ssrn.com/abstract=1828602 (accessed October 2012). 